\title{
Biological Control of Maize Damping - off Disease by Microorganisms Aida H. Afify ${ }^{1}$; A. B. B. El-Sayed ${ }^{2}$ and Seham, E. M. Elpana ${ }^{1}$. ${ }^{1}$ Dept. Microbiology, Fac. Agric. Mansoura Univ., Mansoura, Egypt. \\ ${ }^{2}$ Plant Pathology Research Institute, Agricultural Research Center (A.R.C), Giza, Egypt.
}

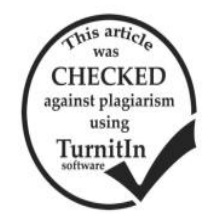

\section{ABSTRACT}

Pythium ultimum is important soil born fungus causing damping - off of maize. Twelve bacterial isolates were obtained from naturally rhizosphere maize. In vitro four bacterial isolates gave comparable results against the pathogen fungus. Two bacterial isolates which showing highly antagonism in vitro and also in vivo, it was identified by standard tests and by the application of biolog system belonging to Microbacterium maritypicum and Bacillus subtilis, while three fungi of Trichoderma spp. were successfully used by several investigators to control .Under greenhouse conditions, the highest percentage of survival plants with Microbacterium maritypicum , Bacillus subtilis, Trichoderma viride, T. harzianum and T. hamatum were $(60 \%, 60 \%, 43.33 \%, 56.67 \%, 43.33 \%)$ respectively in the case of kernels soaking. Hence these bacteria and fungi can be used as an effective biological control agents in maize cultivation.

Keywords:Microbacterium maritypicum, Bacillus subtilis, Biological control, Pythium ultimum, Trichoderma spp.

\section{INTRODUCTION}

Maize (Zea maysL.) is considered the third cereals crops after wheat and rice all over the world for production and consumption. Maize is multipurpose crop, provides food for the human, beings feed for animals, poultry and fodder for livestock. Moreover, it is also used for industrial purposes such as glue, soap, paint, insecticides, toothpaste, shaving cream, rubber tries, rayon, molded plastics, fuels and other ( White and Johnson, 2003). It has high nutritional value as it contains about $72 \%$ starch, $10 \%$ proteins, $4.8 \%$ oil, $8.5 \%$ fibers, $3.0 \%$ sugar and $1.7 \%$ ash ( Chaudhary, 1983).

Several Pythium species including $P$. aphanidermatum, $P$. irregular and $P$. ultimum are know to cause damping- off in greenhouses on different plant species (Chen and Nelson, 2008). Seedling diseases can be caused by several common soil - born organisms, such as Pythium, Fusarium, Rhizoctonia, and plant parasitic nematodes. Seedling diseases are often difficult to diagnose because they have similar symptoms. Diagnosis of a specific disease may be of limited value because management may be similar for several seedling diseases. At least 14 species of Pythium have been previously identified that can cause seedling blight and root rot (Vincelli, 2008).

Biological control of plant pathogens is becoming important for plant disease management and several successful attempts have been made to control the pathogens by microorganisms including Actinomycetes , Bacillus spp., Pseudomonas spp. and Trichoderma spp. (Cook and Granados, 1991).

The aim of the present study was planned to study the possibility of controlling maize damping -off disease by using some bioagents in laboratory and greenhouse conditions.

\section{MATERIALS AND METHODS}

Source of soil samples:

The soil samples were collected from two different governorates namely; El-Dakahlia and ElGharbia governorates in Egypt. These samples were taken for microbiological examination and preserved in fridge and examined within week from collection.
Rhizospheric soils removed by shaking of plant roots were collected.

Isolation and purification of bacteria:

The bacteria were isolated and purified on NA medium(Skerman, 1967) .

Fungal strains:

Three fungal strains namely: Trichoderma viride, T. harzianum and T. hamatum were obtained from Agric. Res. Center, Giza, Egypt.

Fungal pathogen strain:

The pathogen Pythium ultimum was used in these experiment namely soil-born fungi. The standard culture of this fungs was obtained from Agric. Res. Center, Giza, Egypt .

Host plant:

Maize (Zea mays L.) cultivar Balady it provided by Agric. Res. Center, Giza, Egypt .

In vitro experiment:

Antagonism the bacterial isolates, Trichoderma spp. and the pathogen fungus:

This experiment was carried out to study the relationship between the tested pathogenic fungus (P.ultimum) and bioagents according to Ferreira et al., 1991 .

Identification of bacterial isolates:

The isolates of bacteria were selected that gave comparable results were identified by morphologicals and biochemicals tests according to Bergy's Manual of Systematic Bacteriology (2005), and by the application of Biolog system in the MIRCEN, Cairo , Egypt (Biolog, 2013).

In vivo experiment:

Soil infestation technique:

Sandy-clay soil was prepared by mixing sand and clay (1:2) and sterilizing by $5 \%$ formalin solution. The pots $(35 \mathrm{~cm}$ diameter ) supplied with $5 \mathrm{~kg}$ of the prepared soil were used. Infestation was carried out by fungs under the study at the rate of $2 \%$ of potted soil and the pots were moisted with water for 1 week before sowing.

Disease assessment:

Disease assessment was carried out by record the percentage of pre, post-emergence after 15, 45 days and survived plants after sowing, respectively as follow: 


\section{Pre-emergence damping-off $\%=$ Noof non garminated reeds $\times 100$ \\ Total sultwatred seed \\ Post-emergence damping-off $\%=$ Woof dead seadling $\times 100$ \\ Total cultivated seed; \\ Survival plants $\%=\frac{\text { Noof stane seedling }}{\text { Total cultiwated seeds }} \times 100$}

Kernels treatment and cultivation:

Kernels of maize was treated with bioagents by soaking. Bioagents bacterial or fungal antagonists, were grown in shaking nutrient broth for three days for bacterial cultures or potato dextrose broth for five days for fungal cultures at $28 \pm 1{ }^{\circ} \mathrm{C}$. After the incubation period, cultures were filtered through filter paper and centrifuged at $5000 \mathrm{rpm}$ for twenty minutes. The supernatants were taken and used for soaking kernels. Soaking was done for over night and kernels were immediately sown . Bacteria or fungi free media were incubated at the same conditions, centrifuged to get the supernatant and used for soaking kernel as acontrol. While kernels coating were moistened with a volume of an aqueous solution of the bioagents sufficient to moist the kernel surface. Talc powder and few drops of solution from arabic gum assisted in coating kernels and air dried before planting. Kernels were cultivated in infested soil (10 kernels/pot). Three replicate pots (No. $35 \mathrm{~cm}$ diameter) were used and uninfested soil acted as a control ( Kommedahl et. al., 1981)and (Singh et. al., 1980).

Parameters of antagonistic compounds : 1-Hydrogen Cyanide (HCN) :

Production of HCN was detected according to the method of Lorck (1948)

\section{2-Indole Acetic Acid (IAA):}

Production of IAA was detected according to the method of Patten and Glick (2002).

3-Cellulase production:

Aerobic cellulose decomposition was determined using Dubos medium (Allen, 1959).

\section{4-Chitinase production:}

Colloidal chitin was prepared according modified method as described by Faramarzi et al., (2009).

Statistical analysis:

Duncan's multiple range test (MRT) was applied for comparing means under the study (Duncan, 1955).

\section{RESULTS AND DISCUSSION}

Effect of different bacterial isolates against fungus pathogen under laboratory conditions:

Tweleve bacterial isolates were recovered from soils samples and tested in vitro antagonism against $P$. ultimum caused damping-off, the results obtained are presented in Table (1) .Two bacterial isolates (No. $10 \& 11)$ were selected because gave better results (Sagahón,et al.,2011).

Data presented in Table (2) showed that Trichoderma spp. actively affected the growth of the pathogen under the study and slight differences between them were observed. T. hamatum was the most potent inhibitor to the growth of Pythium ultimum than
T. viride and T.harzianum (Moussa,2002 ;Kazempour, 2004 and Abo-Elnaga,2013).

Table 1. Selecting of different bacterial isolates to antagonism against Pythium ultimum .

\begin{tabular}{lc}
\hline $\begin{array}{l}\text { Bacterial isolates } \\
\text { No. }\end{array}$ & $\begin{array}{c}\text { Pythium ultimum } \\
\text { Inhibition zone (cm) }\end{array}$ \\
\hline 1 & 0.0 \\
2 & $0.33 \mathrm{~d}$ \\
3 & 0.0 \\
4 & 0.0 \\
5 & 0.0 \\
6 & 0.0 \\
7 & 0.0 \\
8 & $1.63 \mathrm{a}$ \\
9 & 0.0 \\
10 & $0.63 \mathrm{c}$ \\
11 & $1.23 \mathrm{~b}$ \\
12 & 0.0 \\
Control & 0.0 \\
\hline
\end{tabular}

Means within a column with the same letter are not significantly different at $5 \%$ level.

Table 2. Effect of fungal isolates on the linear growth against Pythium ultimum

\begin{tabular}{lc}
\hline Fungal strains & Pythium ultimum \\
\hline$T$. viride & + \\
T.harzianum & + \\
T. hamatum & ++ \\
\hline
\end{tabular}

(++)inhibition of pathogen by over growth

(+)inhibition of pathogen

Identification of bacterial isolates:

Data in Table (3) showed two isolates of bacteria were identificated by morphological and biochemical characteristics tests according to Bergy's Manual of Systematic Bacteriology (2005) and (Biolog, 2013). The isolate (No. 10) belonging to Microbacterium maritypicum and isolate (No. 11) was Bacillus subtilis.

Table 3. Morphological and biochemical characteristics of the effective bacterial isolates

\begin{tabular}{|c|c|c|}
\hline \multirow{2}{*}{$\begin{array}{l}\text { Tests } \\
\text { Morphological characters }\end{array}$} & \multicolumn{2}{|c|}{ Bacterial isolates No. } \\
\hline & 10 & 11 \\
\hline Gram stain & + & + \\
\hline Spore forming & + & + \\
\hline Motility & + & + \\
\hline Capsule formation & - & + \\
\hline Measurement $(\mu \mathrm{m})$ & $(1 \times 6)$ & $(1 \times 4)$ \\
\hline \multicolumn{3}{|l|}{ Biochemical characters } \\
\hline Indole production & - & - \\
\hline Voges proskauer test & + & + \\
\hline Methyl Red test & + & + \\
\hline Citrate utilization & + & + \\
\hline Catalase production & + & + \\
\hline Starch hydrolysis & + & + \\
\hline Casein hydrolysis & + & + \\
\hline Gelatin liquefaction & + & + \\
\hline Cellulase production & - & - \\
\hline Glucose assimilation & - & + \\
\hline Manitol assimilation & - & + \\
\hline Sucrose assimilation & + & - \\
\hline Fructose assimilation & + & + \\
\hline Lactose assimilation & - & - \\
\hline Dextrin assimilation & - & - \\
\hline Xylose assimilation & - & - \\
\hline Glycerol assimilation & - & - \\
\hline
\end{tabular}




\section{Greenhouse experiments:}

Data in Table (4) showed significant differences between the bioagents tested in controlling damping-off for two methods of seed treatments. All of the tested bioagents for both methods applications are effective in reducing pre- and post-emergence damping-off; and increased survival plants caused by Pythium ultimum . Results of kernels soaking with tested by Microbacterium maritypicum and B.subtilis showed that the most effective in controlling damping -off disease with the same percent of survival plants
(60.00\%) followed by $T$. harzianum ( $56.67 \%)$, other bioagents fell in between compared with the control $(13.33 \%)$. Also, data presented in (Table 4) indicated that kernels coating with $T$. harzianum was the most effective in controlling disease, hence it gave the highest survival plants( $53.33 \%)$, followed by $T$. viride $(43.33 \%)$. On the other hand Microbacterium maritypicum was the lowest in controlling damping off and reducing survival plants (36.67\%) compared with the control( $20.00 \%)$.

Table 4. Effect of bioagents with two kernels methods of application on controlling maize damping - off disease caused by $P$.ultimum.

\begin{tabular}{lcccccc}
\hline Treatments & $\begin{array}{c}\text { Kernels soaking } \\
\text { Damping- off \% } \\
\text { Pre- }\end{array}$ & $\begin{array}{c}\text { Post- } \\
\text { emergence }\end{array}$ & $\begin{array}{c}\text { Survival } \\
\text { \% }\end{array}$ & $\begin{array}{c}\text { Kernels coating } \\
\text { Damping- off \% } \\
\text { Pre- } \\
\text { emergence }\end{array}$ & $\begin{array}{c}\text { Post- } \\
\text { emergence }\end{array}$ & $\begin{array}{c}\text { Survival } \\
\%\end{array}$ \\
\hline Microbacterium maritypicum & $16.67^{\mathrm{c}}$ & $23.33^{\mathrm{bc}}$ & $60.00^{\mathrm{a}}$ & $33.33^{\mathrm{ns}}$ & $30.00^{\mathrm{a}}$ & $36.67^{\mathrm{ab}}$ \\
B.subtilis & $26.67^{\mathrm{bc}}$ & $13.33^{\mathrm{c}}$ & $60.00^{\mathrm{a}}$ & $40.00^{\mathrm{ns}}$ & $16.67^{\mathrm{ab}}$ & $43.33^{\mathrm{ab}}$ \\
T. viride & $20.00^{\mathrm{c}}$ & $36.67^{\mathrm{ab}}$ & $43.33^{\mathrm{a}}$ & $46.67^{\mathrm{ns}}$ & $10.00^{\mathrm{b}}$ & $43.33^{\mathrm{ab}}$ \\
T. harzianum & $20.00^{\mathrm{c}}$ & $23.33^{\mathrm{bc}}$ & $56.67^{\mathrm{a}}$ & $30.00^{\mathrm{ns}}$ & $16.67^{\mathrm{ab}}$ & $53.33^{\mathrm{a}}$ \\
T. hamatum & $33.33^{\mathrm{abc}}$ & $23.33^{\mathrm{bc}}$ & $43.33^{\mathrm{ab}}$ & $33.33^{\mathrm{ns}}$ & $30.00^{\mathrm{a}}$ & $36.67^{\mathrm{ab}}$ \\
Control & $46.67^{\mathrm{a}}$ & $40.00^{\mathrm{ab}}$ & $13.33^{\mathrm{c}}$ & $50.00^{\mathrm{ns}}$ & $30.00^{\mathrm{a}}$ & $20.00^{\mathrm{b}}$ \\
\hline
\end{tabular}

In the same column, means followed by the same letter are not significantly different at $5 \%$ level

The results in the greenhouse are in agreement with Abada, 1994, El-Kazzaz et al.,2000; Moussa and Rizk, 2002; Islam et al., 2007; and Eid 2014. Beet root rot was found also, throughout the present investigation to be affected by bioagent treatments. It was reported that treatment seed with biocontrol agents is the most effective and economical method of introducing the bioagents against seed and soil - borne pathogens. They prevent seed decay, seedling blight or pre-emergence damping off diseases. Trichoderma spp.and Bacillus subtilis were successfully used by several investigators to control some major diseases that affect field crops such as a sugar beet by seed treatments Moussa (2002).

Several modes of action of Trichoderma spp. and Gliocladium spp. were proposed to explain it fungal activity. The antifungal activity of Trichoderma spp. and Gliocladium spp. was attributed to mycoparasitism, competition and antibiosis (Kazempour ,2004).

Parameters for antagonistic from bacteria and fungi:

Production of HCN, IAA and enzymes:

Data presented in Table (5) indicated that all bacterial isolates were negative for $\mathrm{HCN}$ and cellulase .

Table 5. Detection of antagonistic properties of bacteria and fungi :

\begin{tabular}{lcccc}
\hline Microorganisms & HCN & IAA & Cellulase & Chitinase \\
\hline Microbacterium & - & + & - & + \\
maritypicum & & & & + \\
B.subtilis & - & + & - & + \\
T. viride & + & + & - & - \\
T. harzianum & + & + & - & - \\
T. hamatum & + & + & - & - \\
\hline
\end{tabular}

Similar results were obtained by Singh et al., (2008) while two bacterial isolates were only poitive for IAA and chitinase.On the other hand all fungal isolates were only done with $\mathrm{HCN}$ and IAA production .These results are agreement with Ashour and Afify (2017) and Bayoumy et al., (2017).

\section{REFERENCES}

Abada, K.A. (1994). Fungi causing damping-off and root-rot on sugar beet and their biological control with Trichoderma harzianum. Agric., Ecosystems and Environment, 51(3): 333-337.

Abo-Elnaga, H . I .G .(2013). Photosynthetic efficiency promotion of sugar beet by formulation of Trichoderma and control of some sugar beet disease seedling. Agrotechnol. 3: 1000127.

Ashour, A.Z.A. and Aida, H. Afify (2017). Antagonistic effect of Plant Growth Promoting Rhizobacteria (PGPR) as biocontrol of plants damping-off. J. Agric. Chem. and Biotech., Mansoura Univ. Vol. 8 (4) :112-119.

Allen, O. N. (1959).Experiments in soil bacteriology .Bargess Pubi.Co.Minneapoles 15, Minnesota..

Bayoumy, Samia, M.M.; Aida, H. Afify; A.B.B. ElSayed and Samar, S. A. Elshall (2017). Antagonistic effect of Bacillus spp. against sugar beet pathogen Fusarium wilt. J. Agric. Chem.and Biotech.Vol.8(6):177-181.

Bergy's Manual of Systematic Bacteriology (2005).Don, J.; Noel, R.K. and James T.S.2nd ed. Vol.2. George, M. U.S.A.,325-340.

Biolog, D.B. (2013). Biolog GP Data Base.Release 15G Hayward, CA: Biolog. 
Chaudhary, A . R . (1983). Maize in Pakistan.Punjab Agri. Res. Cord. Board, Univ. Agri. Faisalabad, Pakistan, pp: 312-317.

Chen,M.H. and E. B. Nelson (2008). Seed - colonizing microbes from municipal biosolids compost suppress Pythium ultimum damping - off on different plant species. Phytopathol.98 , 10121018.

Cook, R.J. and R.R. Granados (1991). Biological control: making it work. In Agricultural Biotechnology at the Crossroads. ed MacDonald, M. J. F. Ithaca, NY: National Agricultural Biotechnoloy Council pp. 213-227.

Duncan, D.B. (1955).Multible range and multible F-tes. Biometrics. 11:1-42.

El-Kazzaz, M . K .; M . A . Hassan; K . E . Ghoniem and H . M . El-Zahaby (2000). Biological control of sugar beet root rots caused by certain soil born fungi. The Ninth Congres of Phytopathol.The Egypt Phytopathol. Soc., Giza, Egypt.

Eid, K. E. (2014). Biological control of bean damping off caused by Sclerotium rolfsii. Egypt. J. Phytopathol., 42(1):179-191.

Faramarzi, M.A.; M. Fazeli; M.T. Yazd ; S. Adrangi; K . J . Al-Ahmadi ; N . Tasharrofi and F. A . Mohseni, (2009). Optimization of cultural condition for production chitinase by soil isolate of Massilia timonae. Biotechnolo. 8, 93-99.

Ferreira, J. H . S .; F. N . Mathee and A . C . Thomas (1991). Biological control of Eutyptalota on grapevine by an antagonistic strain of Bacillus subtilis.Phytopathol., 81: 283-287.

Islam, M.N.; A.M. Shamsudd and H.P. Ahmed (2007).Comparative effectiveness of Trichoderma colonized organic wastes in controlling foot and root rot (Sclerotium rolfsii) disease of wheat. African Crop Sci. Conf .

Kazempour, M . N . (2004). Biological control of Rhizoctonia solani the causal agent of rice sheath blight by antagonistic bacteria in green house field condition. Plant Pathol .J.,3 (2):8896.

Kommedahl, T.; C.E. Windels ; G. Sarbini and H.B. Wiley (1981). Variability in performance of biological and fungicidal seed treatments in corn, peas, and soybeans. Protection Ecology 3,55-61.
Lorck, H. (1948). Production of hydrocyanic acid by bacteria. Physiol. Plant. 1: 142-146.

Moussa, A . A . (2002). Studies on biological control of suger beet pathogen Rhizoctonia solani Kuhn. J.of Biological Sci. 2(12):800-804

Moussa, A.A.and M.A.Rizk (2002).Biocontrol of sugar beet pathogen Fusarium solani(Mart.) Sacc.by Streptomyces aureofaciens. Pack. G.Bio. Sci; 5 (5):556-559.

Patten, C . and B . Glick (2002).Role of Pseudomonas putida indole acetic acid in development of the host plant root system. Appl. and Environ. Microbiol. 68: 3795-3801.

Skerman, V.B.D. (1967). A guide to identification of the genera of bacteria. 2 nd ed.The Williams \& Wilkins Co. Baltimore.

Sagahón I. P.; M .A . A. Reyes; H . V. Silva ; R .A . Cuenca; A . T . Jurado; I . O . C. Álvarez and Y . M . Flores (2011). Isolation of bacteria with antifungal activity agains the Phytopathogenic Fungi Stenocarpella maydis and Stenocarpella macrospora. Int. J. Mol. Sci., 5522-5537.

Singh, N.; P. Pandey; R . C . Dubey and D. K . Maheshwar (2008). Biological control of root rot fungus Macrophomina phaseolina and growth enhancement of Pinus roxburghii (Sarg.) by rhizosphere competent Bacillus subtilis BN1. World, J. Microbiol.Biotechnol., 24: 1669-1679.

Singh, P.J. and R.S. Mehrotra( 1980). Biological control of Rhizoctonia bataticola on gram by coating seed with Bacillus and Streptomyces spp. and their influence on plant growth . Plant and Soil, 56:475-483.

Steel, P.G.D. and J.H. Torrie (1960). Principle and procedures of statistics. MCG raw, Hill Co.Inc. New York, 481pp.

Vincelli, P. (2008). Seed and Seedling Diseases of Corn. Plant Pathology Fact Sheet university of Kentucky- college of Agriculture PPFS-AG-C02 .

White, P.J. and L.A. Johnson (2003). Corn: chemistry and technology. 2 nd ed., American Association of Cereal Chemists, St. Paul, MV., USA., ISBN13;9781891127335, page; 892 .

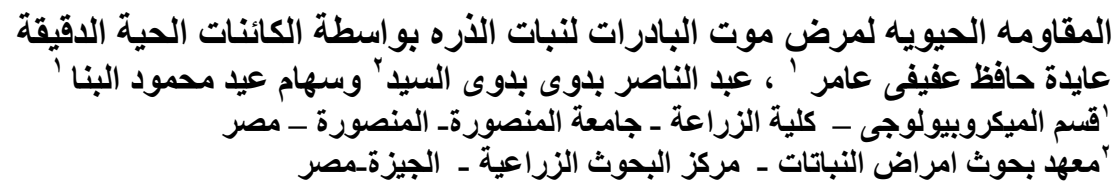

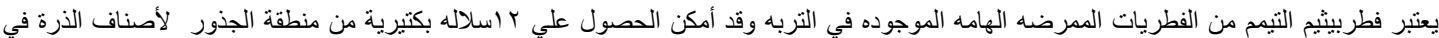

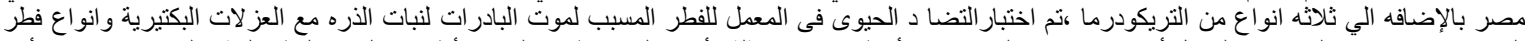

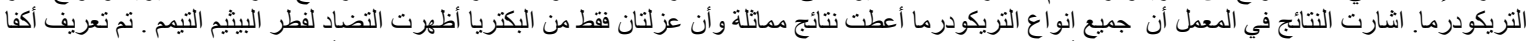

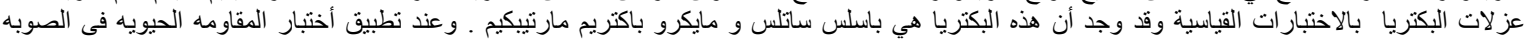

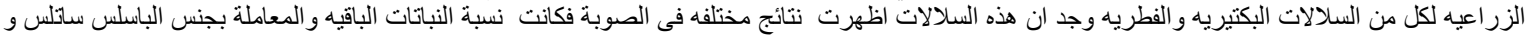

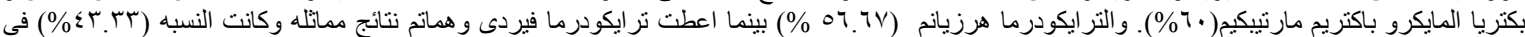

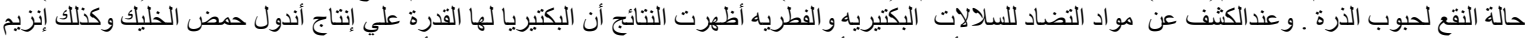

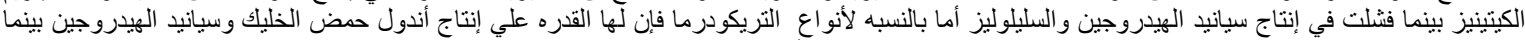

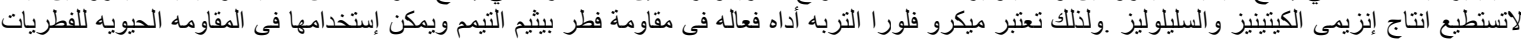
المسبيه لموت البادرات في المحاصيل الاقتصاديه. 